\title{
SUPLEMENTASI KALSIUM PADA IBU HAMIL UNTUK MENGURANGI INSIDENSI PREEKLAMPSIA DI NEGARA BERKEMBANG
}

\author{
CALCIUM SUPPLEMENTATION IN PREGNANT WOMEN TO REDUCE \\ PREECLAMPSIA INCIDENCE IN DEVELOPING COUNTRIES
}

\author{
$\underline{\text { Ria Gustirini }}$ \\ Program Studi DIII Kebidanan STIKes Muhammdiyah Palembang \\ Email : riagustirini@gmail.com
}

\begin{abstract}
ABSTRAK
Preeklampsia adalah gangguan multisistem yang mempersulit 3\%-8\% dari kehamilan dan merupakan salah satu penyebab utama morbiditas dan mortalitas di seluruh dunia. Preeklampsia dalam kehamilan didefinisikan terjadinya hipertensi serta adanya proteinuria pada wanita setelah kehamilan 20 minggu. Sebagian besar kematian ibu yang disebabkan preeklampsia terjadi di negara berkembang. Ibu hamil di negara berkembang telah dilaporkan mengkonsumsi mineral esensial dan vitamin dalam jumlah yang lebih kecil. Pengaruh suplementasi kalsium hanya mungkin relevan untuk populasi dengan asupan dasar kalsium yang rendah yang mungkin terjadi di negara berkembang. Studi ini merupakan suatu tinjauan literatur (literature review) yang memberikan informasi tentang upaya mengurangi risiko pengembangan preeklampsia pada ibu hamil dengan pemberian suplemen kalsium selama kehamilan di negara berkembang. Sumber untuk melakukan tinjauan literature ini meliputi suatu pencarian sistematis database terkomputerisasi dalam bentuk jurnal penelitian yang berjumlah 13 jurnal. Penulisan artikel ilmiah ini menggunakan penulisan daftar pustaka harvard. Level kalsium memainkan peranan penting dalam pathogenesis preeclampsia, ibu hamil preeklampsiaa memiliki kadar kalsium serum yang lebih rendah daripada kelompok normotensif. Kalsium umumnya dapat ditoleransi dengan baik, dosis yang paling efektif untuk suplemen kalsium selama kehamilan adalah $2 \mathrm{~g} / \mathrm{hari}$ dan diberikan mulai dari kehamilan 20 minggu. Ibu hamil di negara berkembang harus di dorong untuk mengkonsumsi makanan yang kaya kalsium, jika asupan kurang dari dosis yang dianjurkan maka suplementasi kalsium perlu diberikan.
\end{abstract}

Kata kunci: suplementasi kalsium, preeklampsia, ibu hamil, negara berkembang

\section{ABSTRACT}

Preeclampsia is a multisystem disorder that complicates 3\% -8\% of pregnancy and is one of the main causes of morbidity and mortality worldwide. Preeclampsia in pregnancy is defined as the occurrence of hypertension and the presence of proteinuria in women after 20 weeks of pregnancy. Most maternal deaths due to preeclampsia occur in developing countries. Pregnant women in developing countries have been reported to consume essential minerals and vitamins in smaller amounts. The effect of calcium supplementation may only be relevant for populations with low calcium intake that may occur in developing countries. This study is a literature review that provides information about efforts to reduce the risk of developing preeclampsia in pregnant women with calcium supplements during pregnancy in developing countries. The source for conducting this literature review includes a systematic search of computerized databases in the form of 14 journal research journals. Writing this scientific article uses the writing of harvard bibliography. Calcium levels play an important role in the pathogenesis of preeclampsia, preeclamptic pregnant women have lower serum calcium levels than the normotensive group. Calcium is generally well tolerated, the most 
effective dose for calcium supplements during pregnancy is $2 \mathrm{~g} /$ day and is given starting from 20 weeks' gestation. Pregnant women in developing countries must be encouraged to consume foods rich in calcium, if the intake is less than the recommended dose, calcium supplementation needs to be given.

Keywords: calcium supplementation, preeclampsia, pregnant women, developing countrie

\section{PENDAHULUAN}

Preeklampsia adalah gangguan multisistem yang mempersulit 3\%-8\% dari kehamilan dan merupakan salah satu penyebab utama morbiditas dan mortalitas di seluruh dunia. Secara keseluruhan, 10-15\% kematian ibu langsung berhubungan dengan preeklampsia dan eklamsi. Preeklampsia merupakan komplikasi medis yang paling umum terjadi pada kehamilan, (Uzan et al., 2011) preeklampsia dalam kehamilan didefinisikan terjadinya hipertensi serta adanya proteinuria pada wanita setelah kehamilan 20 minggu. Sebagian besar kematian ibu yang disebabkan preeklampsia terjadi pada negara berkembang dan negara dengan populasi penduduk berpenghasilan rendah sampai menengah. Dampak terbesar dari preeklampsia terjadi di negara berkembang dimana kejadian preeklampsia sebesar $20-80 \%$ dari angka kematian ibu.(Kanagal et al., 2014, Dodd et al., 2014, Imdad et al., 2011)

Malnutrisi pada ibu hamil umumnya terjadi di negara berkembang dikarenakan konsumsi mineral esensial dan vitamin dalam jumlah yang lebih kecil. Asupan yang kurang memadai akan berdampak pada ibu dan pertumbuhan janin, terdapat bukti yang menunjukkan peran suplemen mikronutrien dalam mencegah berbagai gangguan kehamilan.(Imdad et al., 2011)

Pentingnya nutrisi yang tepat sebelum dan selama kehamilan bermanfaat dalam mengoptimalkan kesehatan ibu dan bayi. Kalsium adalah mikronutrien terbaik yang telah dipelajari dalam hubungannya dengan preeklampsia. Beberapa penelitian epidemiologi pada negara berkembang menunjukan hubungan antara penurunan asupan kalsium dan preeklampsia.(Kanagal et al., 2014)

Terdapat bukti bahwa perubahan metabolisme kalsium sebagai faktor penting dalam pengembangan terjadi preeklampsia. Beberapa penelitian klinis membahas mengenai suplementasi kalsium selama kehamilan. Suatu meta analisis dari berbagai penelitian randomized contol trials yang menunjukan bahwa pemberian kalsium selama kehamilan dapat mencegah kejadian preeklampsia.(Imdad et al., 2011).

\section{METODE PENELITIAN}

Artikel ini merupakan studi tinjauan literatur (literature review) atau mini review artikel yang memberikan informasi tentang upaya mengurangi risiko terjadinya preeklampsia pada ibu hamil dengan pemberian suplemen kalsium selama kehamilan di negara berkembang. Sumber untuk melakukan tinjauan literature ini meliputi suatu pencarian sistematis database terkomputerisasi (Pubmed, Hindawi, 
WHO, Google Scholar, dan Cohraine) dalam bentuk jurnal penelitian yang berjumlah 13 jurnal. Penulisan daftar pustaka artikel ilmiah ini menggunakan penulisan daftar pustaka Harvard, dimana penulisan daftar pustaka ditulis berdasarkan alphabet.

\section{HASIL DAN PEMBAHASAN}

\section{Preeklampsia}

Preeklampsia adalah kondisi khusus di pertengahan kehamilan yang mempengaruhi sekitar 3\%-8\% dari ibu hamil dan memberikan kontribusi yang signifikan baik pada morbiditas dan mortalitas maternal dan perinatal. Secara keseluruhan, 10-15\% dari kematian ibu secara langsung berhubungan dengan preeklampsia dan eklamsi. Preeklampsia adalah faktor yang terjadi sampai dengan sepertiga dari semua kasus morbiditas yang serius dengan $5 \%$ dari wanita membutuhkan perawatan intesif dan dalam jangka panjang dapat meningkatkan risiko wanita pada hipertensi kronis dan penyakit kardiovaskuler. Preeklampsia juga merupakan faktor yang berkontribusi hingga 2,7\% dari seluruh kematian perinatal. Preeklampsia dikaitkan sebagai faktor penyebab hingga $12 \%$ pertumbuhan janin terhambat dan 19\% kelahiran premature yang dapat meningkatkan risiko komplikasi neonatal termasuk sindrom gangguan nafas, hipoglikemia, kejang, perdarahan intra karnial dalam jangka panjang dapat meningkatkan risiko keterlambatan perkembangan saraf pada anak, obesitas, dan penyakit kardiovaskuler di kemudian hari.(Kanagal et al., 2014, Uzan et al., 2011)

Preeklampsia diklasifikasikan menjadi preeklampsia ringan dan preeklampsia berat. Kriteria untuk menentukan preeklampsia tidak berubah dalam dekade terakhir, preeklampsia ringan yaitu terjadi pada usia kehamilan lebih dari 20 minggu, proteinuria $\geq 300 \mathrm{mg} /$ hari $(\geq 1+$ pada dipstick), tekanan darah sistolik $>140 \mathrm{~mm} \mathrm{Hg}$, tekanan darah diastolic $\geq 90 \mathrm{mmHg}$ atau peningkatan tekanan darah sistolik $\geq 30$ $\mathrm{mmHg}$ dan diastilok $\geq 15 \mathrm{mmHg}$ dari batas dasarnya, pengukuran dilakukan sebanyak dua kali dengan jarak 4-6 jam, sedangkan preeklampsia berat tekanan darah $\geq 160 / 110 \mathrm{~mm} \mathrm{Hg}$, proteinuria $\geq 5 \mathrm{~g} /$ hari $(\geq 3+$ pada dipstick) disertai kenaikan kreatinin, oliguria $<500 \mathrm{cc} /$ hari, gangguan neurologis seperti sakit kepala terus menerus, HELLP Syndrom. Ibu hamil dengan Preeklampsia dapat normal kembali sebelum postpartum minggu ke-enam.(Hladunewich et al., 2007, Imdad et al., 2011)

Meskipun demikian etiologi preeklampsia belum diketahui dengan pasti karena melibatkan berbagai sistem dan multi faktor, namun faktor genetik, lingkungan dan gizi mungkin memainkan peran dalam etiologi preeklampsia. Faktor risiko preeklampsia adalah nulipara, riwayat preeklampsia, obesitas, diabetes mellitus, usia $>$ 35 tahun di kehamilan pertama dan merokok. Penelitian di finlandia menemukan bahwa ibu hamil dengan usia tua merupakan faktor risiko yang signifikan untuk mengembangkan preeklampsia, serta BMI secara signifikan lebih tinggi pada kelompok hipertensi daripada kelompok normotensif ( $<<0.001)$.(Kanagal et al., 2014, López-Jaramillo et al., 2001, Belizan and Villar, 1980) 


\section{Kalsium}

Kalsium merupakan mineral terbanyak yang didapatkan dalam tubuh manusia. Hampir 99\% kandungan kalsium dalam tubuh manusia didapatkan dalam tulang. Kalsium memegang peranan penting dalam berbagai proses fungsi fisiologis didalam tubuh yaitu proses pembekuan darah, bersama dengan natrium dan kalium mempertahankan potensial membrane sel, tranduksi sinyal antara reseptor hormon, eksitabilitas neuromuskuler, integritas membrane sel, pembentukan struktur tulang dan sebagai cadangan kalsium tubuh. Makanan yang kaya kalsium seperti susu, susu kedelai, yogurt, keju, dan sayuran seperti kubis, brokoli, almond, sarden dan salmon, jus jeruk.(Imdad et al., 2011, Kanagal et al., 2014)

Kalsium sangat penting untuk banyak proses yang beragam dalam tubuh, termasuk pembentukan tulang, kontraksi otot, fungsi hormon dan enzim. Konsumsi kalsium yang tidak memadai pada ibu hamil dapat menyebabkan efek samping pada ibu dan janin serta menghasilkan osteopenia, tremor, parestesia, kram otot, tetanus, pertumbuhan janin terhambat, berat badan lahir rendah, dan mineralisasi janin rendah.(Belizan and Villar, 1980)

Selama kehamilan, janin membutuhkan sejumlah besar kalsium untuk perkembangan. Janin menyimpan kalsium sebanyak $28.2 \mathrm{~g}$ kalsium dan $80 \%$ dari jumlah tersebut diperoleh pada trimester ketiga. Sekresi kalsium pada kehamilan meningkat dua kali lipat dibandingkan wanita tidak hamil. Penyesuaian kalsium dalam tubuh ibu merupakan kompensasi terhadap kebutuhan janin dan peningkatan sekresi kalsium. Kadar kalsium dalam plasma ditentukan oleh absorbsi kalsium pada saluran cerna, resorbsi kalsium pada tulang dan pengeluaran kalsium pada tinja, urine dan keringat. Pengaturan keseimbangan kalsium dipengaruhi terutama oleh hormon paratiroid, kalsitonin dan vitamin D.(Belizan and Villar, 1980)

\section{Peran Kalsium dalam Preeklampsia}

Peran kalsium dalam pengembangan risiko preeklampsia selama kehamilan dapat dijelaskan dengan kadar kalsium yang rendah atau faktor-faktor lain selama kehamilan menghasilkan peningkatan tekanan darah. Ibu hamil dengan asupan kalsium tinggi memiliki tingkat tekanan darah stabil yang akan mencegah hipertensi sehingga mengurangi risiko pengembangan preeklampsia.(Belizan and Villar, 1980)

Kekurangan asupan kalsium akan menyebabkan peningkatan hormon paratiroid (PTH) sehingga menyebabkan peningkatan kalsium intraseluler. Peningkatan kalsium intraseluler akan mengakibatkan otot polos pembuluh darah mengalami vasokontriksi sehingga tekanan darah meningkat. Peningkatan tekanan darah selama kehamilan merupakan risiko pengembangan terjadinya preeklampsia.(Khalil and Granger, 2002, Imdad and Bhutta, 2012). 


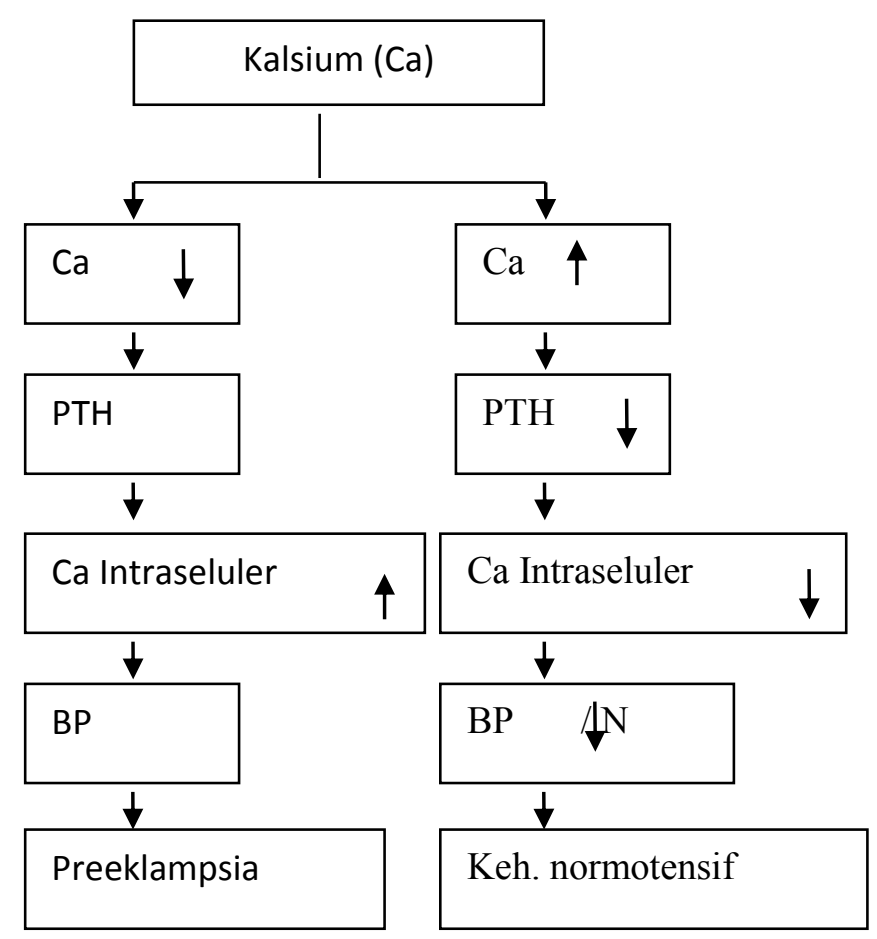

Disisi lain, gizi dan faktor lingkungan sebagai faktor risiko penting dalam preeklampsia, kekurangan gizi yang umumnya terjadi selama kehamilan di negara berkembang adalah asupan mineral dan vitamin yang rendah, seperti rendahnya asupan kalsium. Ketika asupan kalsium rendah, tubuh menggunakan serangkaian mekanisme untuk mempertahankan tingkat ion kalsium serum. Konsentrasi kalsium serum terionisasi tergantung pada asupan kalsium yang memadai. Pada preeklampsia terjadi penurunan konsentrasi kalsium ekstraseluler dengan rendahnya tingkat kalsium serum terionisasi. Konsentrasi kalsium ekstraseluler sangat penting untuk sintesis dalam endothelium seperti prostasiklin dan NO, sehingga dengan kekurangan kalsium tidak hanya kekurangan mineral tetapi juga terkait dengan efek fisiologis yang disebabkan oksidatif stress.(Kanagal et al., 2014). 


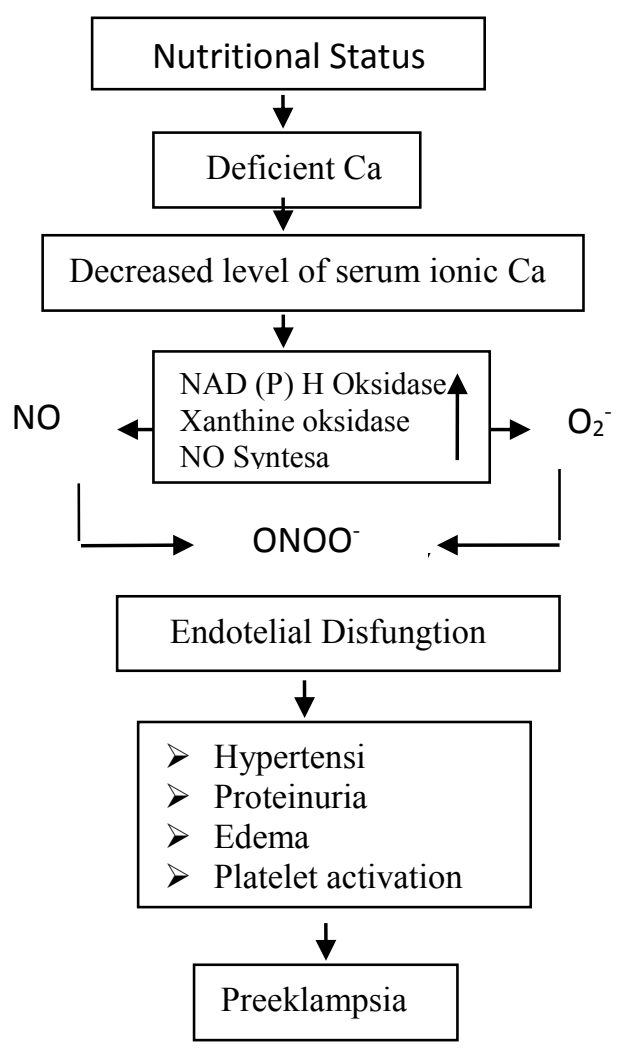

NO merupakan vasodilator kuat yang menyebabkan relaksasi otot polos, studi menunjukan bahwa tingkat NO secara signifikan lebih rendah pada ibu preeklampsia. Superoxide adalah radikal bebas oleh beberapa kondisi patologis seperti preeclampsia. Peningkatan ekspresi oksidase NADPH dan xantin oksidase (XO) menyebabkan produksi Superoxide meningkat. Oksidase NADPH adalah enzim kompleks yang mengkatalis pengurangan satu elektron oksigen menjadi superoxide melalui NADPH, sedangkan aktivitas nitrat oksida sintase juga meningkat secara signifikan pada sel endotel yang terpapar plasma preeklampsia. Reaksi antara NO dan Superoxide menghasilkan peroxyinitrite $\left(\mathrm{ONOO}^{-}\right)$yang menyebabkan disfungsi endothelial. Disfungsi endotel bertanggung jawab atas tanda-tanda klinis preeklampsia yaitu penurunan dari endothelium hepatic berkontribusi untuk timbulnya HELLP sindrom (Hemolisis,Elevated liver enzim, and Low platelet count), menambah penurunan filtrasi glomurulus dan menyebabkan proteinuria, disfungsi endotel mendorong mikroangiopati hemolitik anemia, dan hypermeability vaskuler terkait dengan rendahnya albumin serum penyebab edema. Penurunan endothelium cerebral merangsang refaktori gangguan saraf atau bahkan eklampsia. Kebutuhan kalsium yang cukup sebelum dan pada awal kehamilan mungkin diperlukan untuk mencegah patologi yang mendasari terjadinya preeclampsia.

(López-Jaramillo et al., 2001, Uzan et al., 2011, Sánchez-Aranguren et al., 2014, Imdad and Bhutta, 2012) 


\section{Level Kalsium Serum pada Preeklampsia}

Level kalsium memainkan peranan penting dalam pathogenesis preeklampsia. Penelitian yang dilakukan pada $200 \mathrm{ibu}$ hamil dari kelompok usia 20-35 tahun pada kelompok studi (preeklampsia) dan kelompok kontrol (normotensif) didapatkan bahwa kelompok preeklampsia memiliki kadar kalsium serum yang lebih rendah daripada kelompok normotensif $(\mathrm{p}<0.005)$. (Belizan and Villar, 1980)

\begin{tabular}{|c|c|c|}
\hline Particulars & Nomotensive & Preeclamptic \\
\hline $\operatorname{Mean} \pm S D$ & $8.27 \pm 1.46 \mathrm{mgd}$ & $7,90 \pm 1.22 \mathrm{mgd}$ \\
\hline \% decrease & & $3,79 \%$ \\
\hline pvalue & & $<0,05$ \\
\hline
\end{tabular}

Out put urine dengan konsentrasi kalsium serum yang tinggi pada ibu hamil merupakan mekanisme penyerapan kalsium oleh usus yang meningkat yaitu mencapai dua kali lebih tinggi selama kehamilan. Konsentrasi kalsium serum terionisasi tergantung pada asupan kalsium yang memadai. Pada preeklampsia terjadi penurunan konsentrasi kalsium ekstraseluler dengan rendahnya tingkat kalsium serum terionisasi. Konsentrasi kalsium ekstraseluler sangat penting untuk sintesis dalam endothelium seperti prostasiklin dan NO, sehingga dengan kekurangan kalsium tidak hanya kekurangan mineral tetapi juga terkait dengan efek fisiologis yang disebabkan oksidatif stres. Efek menguntungkan dari suplementasi kalsium dalam pencegahan hipertensi dapat dikaitkan dengan menjaga tingkat kalsium serum terionisasi. Pengukuran tingkat kalsium serum mungkin berguna untuk diagnosis awal dari kondisi preeklampsia sehingga dengan pemberian suplemen kalsium mungkin dapat menurunkan insidensi preeklampsia.(Magnus et al., 2018, Belizan and Villar, 1980, Imdad and Bhutta, 2012)

\section{Suplementasi Kalsium untuk Mengurangi Preeklampsia}

Dosis suplemen kalsium berkisar dari $500 \mathrm{mg} /$ hari sampai $2 \mathrm{~g} /$ hari. Sebuah analisis sub kelompok untuk kejadian preeklampsia dengan dosis $<2$ g/ hari dibandingkan dengan dosis $2 \mathrm{~g} /$ hari menunjukan bahwa efek lebih jelas dan signifikan secara statistik dalam penelitian yang menggunakan dosis $2 \mathrm{~g} /$ hari (RR 0.39 [95\% CI 0.23-0.67]) dibandingkan dengan kelompok yang menggunakan dosis $<2 \mathrm{~g} /$ hari (RR 0.56 [95\% CI 0.30-1.03]). Hal ini menunjukan bahwa dosis yang paling efektif untuk suplemen kalsium selama kehamilan adalah $2 \mathrm{~g} /$ hari dan diberikan mulai dari kehamilan 20 minggu, jumlah kalsium diberikan dalam bentuk dua tablet masing-masing $500 \mathrm{mg}$ dikonsumsi dua kali dalam sehari.(Villar et al., 2006, Imdad and Bhutta, 2012, Uzan et al., 2011).

Pada tinjauan cochrane suplementasi kalsium untuk pencegahan preeklampsia memperoleh manfaat yang signifikan yaitu mengurangi risiko perempuan yang mengembangkan preeklampsia pada masa kehamilan. Penurunan yang signifikan 
dalam risiko preeklampsia berhubungan dengan suplemen kalsium (13 percobaan, 15.730 wanita: RR $0.45,95 \%$ CI $0.31-0.65 ;^{2}=70 \%$ ), Efeknya yang terbesar adalah bagi wanita dengan asupan kalsium yang rendah (delapan percobaan, 10.678 wanita: RR 0.36; 95 CI $0.20-0.65{ }^{2}=76 \%$ ). (Hofmeyr et al., 2006).

Suplementasi kalsium selama kehamilan dikaitkan dengan penurunan yang signifikan terhadap risiko preeklampsia, sebanyak 5.697 wanita dikelompokan pada kelompok intervensi dan 5.708 wanita pada kelompok kontrol pada 10 penelitian RCT menunjukan penurunan 59\% dalam risiko preeklampsia (RR 0.41;CI 0.24-0.69) di negara berkembang. Suplemen kalsium yang diberikan tidak mempunyai pengaruh yang signifikan di negara maju. Food and Drug Administration (FDA) telah menunjukan bahwa efek menguntungkan dari suplementasi kalsium tidak dapat digeneralisasikan pada negara maju, hal ini disebabkan karena perbedaan asupan kalsium dasar pada negara berkembang dalam batas yang rendah $(<900$ $\mathrm{mg} /$ hari).(Imdad et al., 2011)

Asupan suplemen terutama kalsium membantu dalam mengurangi insiden preeklampsia terutama pada populasi di negara berkembang, sebanyak 15 penelitian RCT menunjukan bahwa supelementasi kalsium selama kehamilan mengurangi risiko pengembangan terjadinya preeklampsia sebesar 52\% [(RR) 0.48 ; $95 \%$ (CI) 0.34 0.67]. Suplementasi kalsium pada ibu hamil dengan diet kalsium yang rendah merupakan strategi pencegahan preeklampsia. Suplementasi kalsium dikaitkan dengan penurunan risiko preeklampsia (RR: 0.70;95\% CI: $0.58-0.83$ ) terutama bagi mereka dengan asupan dasar kalsium yang rendah, dengan demikian suplemen kalsium bermanfaat bagi ibu hamil dari populasi dengan asupan kalsium dasar yang rendah.(Imdad and Bhutta, 2012, López-Jaramillo et al., 2001)

Untuk semua wanita, terlepas dari risiko dasar pengembangan hipertensi dan status asupan kalsium, lebih dari separuh risiko preeklampsia dapat dikurangi dengan suplemen kalsium bila dibandingkan dengan plasebo (rasio risiko rata-rata (RR) 0.48 , 95\% CI 0.34 0.67, 15 percobaan, 16.490 perempuan). Pengurangan risiko ini adalah $41 \%$ untuk wanita berisiko rendah terkena hipertensi (RR 0.59, 95\% CI 0.42-0.82, 10 percobaan, 15.903 perempuan) sedangkan pengurangan risiko terbesar (78\%) pada mereka yang berisiko tinggi hipertensi (RR 0.22 , 95\% CI 0.12-0.42, lima percobaan, 587 wanita). Penurunan risiko memiliki tekanan darah tinggi paling besar di antara wanita yang berisiko tinggi terkena hipertensi (RR 0.47, 95\%CI 0.22-0.9, empat percobaan, 327 wanita) dan di antara mereka dengan asupan awal kalsium yang rendah (RR 0.44, 95\% CI 0.28-0.70, tujuh percobaan, 10.418 perempuan).(Villar et al., 2006).

Kalsium umumnya dapat ditoleransi dengan baik dalam tubuh. Beberapa efek samping ringan seperti sakit kepala, sembelit, mual, muntah, anoreksia, sakit perut, perut kembung dapat terjadi $1-10 \%$ saat pemberian suplemen kalsium, namun pada beberapa kajian literature efek samping dari suplemen kalsium selama kehamilan belum pernah dilaporkan. Komplikasi yang paling ditakuti dari peningkatan asupan kalsium adalah batu ginjal. Data yang dilaporkan dari dua penelitian besar pada kejadian urolitiasis dan kolik ginjal menunjukkan risiko peningkatan yang tidak 
signifikan dalam kelompok intervensi dibandingkan dengan kontrol (RR 1.52 [95\% CI 0.06-40.67] dan RR 1,75 [95\% CI 0.51-5.99], Hal ini menunjukkan bahwa tidak ada peningkatan risiko batu ginjal pada kelompok yang diberi kalsium dibandingkan dengan kontrol. Kalsium dapat mengganggu penyerapan beberapa mineral lain seperti besi atau seng, dan dengan obat-obatan seperti bifosfonat dan tetrasiklin. Namun Interaksi ini sangat mudah dikelola dengan memisahkan suplementasi kalsium dari yang obat atau mineral lain dengan jarak konsumsi 2 jam atau lebih.(Imdad and Bhutta, 2012, Villar et al., 2006)

\section{KESIMPULAN}

Secara umum strategi yang efektif untuk mengurangi risiko pengembangan preeklampsia telah terbukti sangat sulit, hal ini terkait dengan penyebab multifaktor dan melibatkan sistem yang kompleks. Banyak intervensi telah diusulkan dan di evaluasi dalam pencegahan preeklampsia, suplementasi kalsium menjadi salah satu strategi yang terkait dengan pengurangan risiko pengembangan preeklampsia.

Pengaruh suplementasi kalsium hanya mungkin relevan untuk populasi dengan asupan dasar kalsium yang rendah yang mungkin terjadi pada negara berkembang. Ibu hamil di negara berkembang harus di dorong untuk mengkonsumsi makanan yang kaya kalsium, jika asupan kurang dari dosis yang dianjurkan maka suplementasi kalsium perlu diberikan,

Pemberian kalsium selama kehamilan harus direkomendasikan pada negara berkembang atau populasi dengan asupan kalsium yang rendah. Pelaksanaan rekomendasi dari suplemen kalsium untuk semua ibu hamil di negara berkembang menimbulkan tantangan besar bagi para pembuat kebijakan.

\section{DAFTAR PUSTAKA}

Belizan, j. \& villar, j. (1980). The relationship between calcium intake and edema-, proteinuria-, and hypertension-gestosis: an hypothesis. The american journal of clinical nutrition, 33, 2202-2210.

Dodd, j. M., o'brien, c. \& grivell, r. M. (2014). Preventing pre-eclampsia-are dietary factors the key? Bmc medicine, 12, 176.

Hladunewich, m., karumanchi, s. A. \& lafayette, r. (2007). Pathophysiology of the clinical manifestations of preeclampsia. Clinical journal of the american society of nephrology, 2, 543-549.

Hofmeyr, g. J., atallah, á. N. \& duley, 1. (2006). Calcium supplementation during pregnancy for preventing hypertensive disorders and related problems. Cochrane database of systematic reviews.

Imdad, a. \& bhutta, z. A. (2012). Effects of calcium supplementation during pregnancy on maternal, fetal and birth outcomes. Paediatric and perinatal epidemiology, 26, 138-152. 
Imdad, a., jabeen, a. \& bhutta, z. A. (2011). Role of calcium supplementation during pregnancy in reducing risk of developing gestational hypertensive disorders: a meta-analysis of studies from developing countries. Bmc public health, 11, s18.

Kanagal, d. V., rajesh, a., rao, k., devi, u. H., shetty, h., kumari, s. \& shetty, p. K. (2014). Levels of serum calcium and magnesium in pre-eclamptic and normal pregnancy: a study from coastal india. Journal of clinical and diagnostic research: jcdr, 8, oc01.

Khalil, r. A. \& granger, j. P. (2002). Vascular mechanisms of increased arterial pressure in preeclampsia: lessons from animal models. American journal of physiology-regulatory, integrative and comparative physiology, 283, r29-r45.

López-jaramillo, p., casas, j. \& serrano, n. 2001. Preeclampsia: from epidemiological observations to molecular mechanisms. Brazilian journal of medical and biological research, 34, 1227-1235.

Magnus, m. C., miliku, k., bauer, a., engel, s. M., felix, j. F., jaddoe, v. W., lawlor, d. A., london, s. J., magnus, p. \& mcginnis, r. (2018). Vitamin $d$ and risk of pregnancy related hypertensive disorders: mendelian randomisation study. Bmj, 361, k2167.

Sánchez-aranguren, 1. C., prada, c. E., riaño-medina, c. E. \& lopez, m. (2014). Endothelial dysfunction and preeclampsia: role of oxidative stress. Frontiers in physiology, 5, 372.

Uzan, j., carbonnel, m., piconne, o., asmar, r. \& ayoubi, j.-m. (2011). Pre-eclampsia: pathophysiology, diagnosis, and management. Vascular health and risk management, 7, 467.

Villar, j., abdel-aleem, h., merialdi, m., mathai, m., ali, m. M., zavaleta, n., purwar, m., hofmeyr, j., campódonico, 1. \& landoulsi, s. (2006). World health organization randomized trial of calcium supplementation among low calcium intake pregnant women. American journal of obstetrics and gynecology, 194, 639-649. 